\title{
Analisis Parameter Fisika dan Kimia Air Bersih di Desa Lalumpe Kecamatan Kombi Kabupaten Minahasa
}

\author{
Vlagia Indira Paat ${ }^{* a}$, Anderson Arnold Aloanis ${ }^{b}$, Andre Karundeng ${ }^{c}$ \\ a FMIPA, Universitas Kristen Indonesia Tomohon, Kota Tomohon, 95411, Indonesia \\ ${ }^{b}$ Ilmu Kimia FMIPA, Universitas Negeri Manado, Tondano, 95618, Indonesia \\ c Balai Teknik Kesehatan Lingkungan dan Pengendalian Penyakit, Manado, 95256, Indonesia
}

\begin{tabular}{l} 
I N F O AR T I KE L \\
\hline Diterima 6 April 2018 \\
Disetujui 30 April 2018 \\
\\
\hline Key word: \\
clean water \\
physical pa rameters \\
chemical parameters \\
\hline Kata kunci: \\
Airbersih \\
Parameter fisika \\
Parameter kimia \\
\hline
\end{tabular}

\begin{abstract}
A B S TR A C T
A research on physical and chemical parameters on clean water in Lalumpe village, Kombi district has been done. . Water sampling is done by purposive sampling method. Samples were taken 2 times and then analyzed the physical and chemical parameters in the laboratory of Balai Teknik Kesehatan Lingkungan dan Pemberantasan Penyakit Menular Kelas 1 Manado. From the research results, clean water samples are categorized well and feasible to use because all parameters both physics and chemistry are analyzed below the threshold quality standard required based on the standard of environment al health standard for water media for sanit any hygiene purposes
\end{abstract}

\begin{abstract}
A B S TR A K
Penelitian mengenai analisis parameter fisika dan Kimia air bersih di desa Lalumpe Kecamatan Kombi telah dilakukan. Pengambilan sampel air bersih dilakukan dengan metode purposive sampling. Sampel diambil sebanyak 2 ka li kemudian diana lisis parameter fisika dan kimianya di laboratorium Balai Teknik Kesehatan Lingkungan dan Pemberantasan Penyakit Menular Kelas 1 Mana do. Da ri hasil penelitian, sampel air bersih dika te gorikan baik dan layak digunakan karena semua parameter baik fisika dan kimia yang dianalisis menunjukkan nilai diba wah a mbang ba tas yang dipersyaratkan berdasarkan standart bakumutu kesehatan lingkungan untuk media air untuk keperluan higiene sanitasi.
\end{abstract}

\section{Pendahuluan}

Air merupakan sumber daya alam yang diperlukan untuk hajat hidup orang banyak, bahkan oleh semua makhluk hidup. Semakin naik jumlah penduduk serta laju pertumbuhannya maka semakin meningkat pula laju pemanfaatan sumber-sumber air . Seiring dengan berjalannya waktu, perkembangan peradaban serta bertambahnya jumlah penduduk akan menambah aktivitas kehidupan yang menambah pengotor atau pencemaran air [1]

Air merupakan faktor penting dalam pemenuhan kebutuhan vital bagi mahluk hidup diantaranya sebagai air minum atau keperluan rumah tangga lainnya. Air yang digunakan harus bebas dari kuman penyakit dan tidak mengandung bahan beracun. Sumber air minum yang memenuhi syarat sebagai air baku air minum jumlahnya makin lama makin berkurang sebagai akibat ulah manusia sendiri baik sengaja maupun tidak disengaja [2].

Air sebagai pelarut universal, memiliki kemampuan untuk melarutkan berbagai zat, mulai fasa gas dari udara, fasa cair dari berbagai larutan, fasa padat dan juga mikroorganisme. Oleh karena itu air banyak sekali mengandung berbagai zat terlarut maupun tidak terlarut, 
sehingga air sangat sukar diperoleh dalam keadaan murni. Apabila kandungan berbagai zat tersebut tidak mengganggu kesehatan manusia, maka air dianggap bersih. Air dikatakan tercemar apabila terdapat gangguan terhadap kualitas air, dimana kandungan berbagai zat sudah melebihi ambang batas. Ambang batas kadar zat dalam air berbedabeda untuk jenis air sesuai peruntukannya. Misalnya kadar zat untuk air minum berbeda ambang batasnya dengan kadar suatu zat untuk industri [3].

Lalumpe adalah sebuah nama desa di wilayah kecamatan Kombi, kabupaten Minahasa, Provinsi Sulaw esi Utara.dengan luas daerah 1.225 Ha dan jumlah penduduk 1100 jiwa. Ada dua sungai besar yang mengalir diwilayah desa lalumpeyaitu sungai Kaw is dan Sungai Tulaun. Masyarakat di desa Lalumpe menggunakan air yang berasal dari sungai ini untuk memenuhi kebutuhan sehari - hari. Air sungai ditampung dalam bak besar kemudian dialirkan ke rumah warga.

Oleh karena itu penelitian mengenai kualitas air bersih yang digunakan di desa Lalumpe menjadi hal yang menarik untuk dilakukan terutama bila dikaitkan dengan standar baku mutu air yang sesuai dengan keputusan Menteri Kesehatan Republik Indonesia

\section{Bahan dan Metode}

Alat yang digunakan adalah Spektrofotometer Serapan Atom (AAS), Spektrofotometer UV-Vis, erlenmeyer, $\mathrm{pH}$ meter, buret, labu ukur, gelas piala, termometer, pipet gondok, neraca analitik, hot plate, labu semprot, pipet tetes dan magnetik stirer.Bahan yang digunakan adalah sampel air bersih di Desa Lalumpe Kecamatan Kombi , buffer $\mathrm{pH}$ 4, 7 dan 10 untuk standarisasi $\mathrm{pH}$ meter

Metode pengambilan sampel pada penelitian ini adalah purposive sampling. Pengambilan sampel dilakukan 2 kali yaitu pada saat hujan dan pada saat tidak hujan. Selanjutnya dianalisis di Balai Teknik Kesehatan Lingkungan dan Pemberantasan Penyakit Menular Kelas 1 Manado.

Data yang diperoleh dianalisis secara deskriptif kemudian dibandingkan dengan baku mutu air berdasarkan Peraturan Pemerintah Nomor 32 tahun 2017 tentang Pengelolaan Kualitas Air Dan Pengendalian Pencemaran Air.

\section{Hasil dan Pembahasan}

Berdasarkan hasil analisis parameter kualitas air bersih di Desa Lalumpe, dapat dikatakan dalam kategori baik karena semua indikator untuk parameter fisika dan kimia yang diuji memenuhi bakumutu yang ditetapkan seperti yang terlihat pada Tabel 1 .

\begin{tabular}{ccccc}
\multicolumn{3}{c}{ Tabel 1. Hasil Pengukuran Parameter Fisika } \\
dan Kimia Air Bersih di Desa Lalumpe
\end{tabular}

Pada Tabel 1 dapat kita lihat bahwa semua indikator yang dianalisis masih dibawah ambang batas yang ditetapkan pemerintah untuk menjadikan suatu sumber air dapat digunakan untuk keperluan higiene sanitasi.

Pada parameter fisika yang diuji adalah kekeruhan dan total zat padat terlarut. Dari 2 sampel air bersih yang dianalisis keduanya masih memungkinkan dikatakan dalam kategori baik. Kekeruhan pada air umumnya disebabkan oleh adanya partikel-partikel suspensi seperti tanah liat, lumpur, bahanbahan organik terlarut, bakteri, plankton dan 
organisme lainnya . Kekeruhan erat kaitannya dengan nilai TDS dalam air. Semakin tinggi nilai TDS dalam air maka akan semakin tinggi pula nilai kekeruhan dalam air. [4]

Hasil analisis parameter kimia yang meliputi besi, kesadahan, mangan, $\mathrm{pH}$, nitrat,nitrit,sianida untuk sampel air bersih dari desa Lalumpe juga menunjukkan bahw a semua indikator berada dibawah ambang batas yang ditetapkan berdasarkan standart bakumutu kesehatan lingkungan untuk media air untuk keperluan higiene sanitasi.

Pengaruh yang menyangkut aspek kesehatan dari pada penyimpangan standar kualitas air minum dalam hal $\mathrm{pH}$ adalah apabila nilai $\mathrm{pH}$ lebih kecil 6,5 dan lebih besar dari 9,2 dapat menyebabkan beberapa senyawa kimia berubah menjadi racun yang dapat mengganggu kesehatan. Air yang mengandung banyak besi akan berwarna kuning dan menyebabkan rasa logam besi dalam air, serta menimbulkan korosi pada bahan yang terbuat dari metal [5].

Pencemaran air dari nitrat dan nitrit bersumber dari tanah dan tanaman. Nitrat dapat terjadi baik dari $\mathrm{NO}_{2}$ atmosfer maupun dari pupuk-pupuk yang digunakan dan dari oksidasi $\mathrm{NO}_{2}$ oleh bakteri dari kelompok Nitrobacter.Jumlah Nitrat yang lebih besar dalam usus cenderung untuk berubah menjadi nitrit yang dapat bereaksi langsung dengan hemoglobine dalam daerah membentuk methaemoglobine yang dapat menghalang perjalanan oksigen didalam tubuh [2].

\section{Ucapan terimakasih}

Terima kasih kepada pemerintah Desa Lalumpe,Kecamatan Kombi yang telah mengizinkan penelitian ini dilakukan..

\section{Kesimpulan}

Dari hasil penelitian dapat disimpulkan bahwa kualitas air bersih di Desa Lalumpe Kecamatan Kombi, Minahasa baik karena hasil analisis parameter fisika dan kimia menunjukkan nilai yang berada di bawah ambang batas dari standart bakumutu kesehatan lingkungan untuk media air untuk keperluan higiene sanitasi.

\section{Daftar Pustaka}

1. Rahayu,B.,Napitupulu,M,Tahril. Analisis Logam Zink dan Besi Air Sumur Di Kelurahan Pantoloan Kecamatan Palu Utara.J. Akad. Kim. 2(1). 2013

2. Wulan,Anisa. Skripsi. Kualitas Air Bersih Untuk Pemenuhan Kebutuhan Rumah Tangga di Desa Pesarean Kecamatan Adiwerna Kabupaten Tegal. Universitas Negeri Semarang.2005

3. Hendrawati. Analisis Beberapa Parameter Kimia Dan Kandungan Logam Pada Sumber Air Tanah Di Sekitar Pemukiman Mahasiswa UIN Syarif Hidayatullah Jakarta. Jakarta.2007

4. Effendi, Hefni. Telaah Kualitas Air Bagi Pengelolaan Sumber Daya dan Lingkungan Perairan. Kanisius : Jakarta.2003

5. Sulistyorini,I.S.,Edwin,M.,SampeArung,A 2016. Analisis Kualitas Air Pada Sumber Mata Air di Kecamatan Karangan Dan Kaliorang Kabupaten Kutai Timur. Jurnal Hutan Tropis Volume 4 No.1 